\title{
Purification and Characterization of Turnip Mosaic Virus Helper Component Protein
}

\author{
R. Y. Wang and T. P. Pirone
}

Department of Plant Pathology, University of Kentucky, Lexington 40546.

Accepted for publication 16 March 1999.

\section{ABSTRACT}

Wang, R. Y., and Pirone, T. P. 1999. Purification and characterization of turnip mosaic virus helper component protein. Phytopathology 89:564567.

The helper component (HC) protein of turnip mosaic virus (TuMV) was concentrated by differential centrifugation followed by ammonium sulfate precipitation. The partially purified $\mathrm{HC}$ was then loaded onto a $\mathrm{Ni}^{2+}$ resin column that bound the $\mathrm{HC}$; a histidine tag was not required for binding. The $\mathrm{HC}$ eluted from the column migrated as a band of about $50 \mathrm{kDa}$ in sodium dodecyl sulfate-polyacrylamide gel electrophoresis. In its native state, the HC did not pass through an ultrafiltration membrane with a molecular mass cutoff of $100 \mathrm{kDa}$, which suggested that the $\mathrm{HC}$ is in a multimeric form when it is biologically active. The molecular mass of the multimeric form was determined by gel filtration to be approximately $145 \mathrm{kDa}$. Purified $\mathrm{HC}$ retained its activity for several months at $-20^{\circ} \mathrm{C}$. Using a protein blotting-overlay protocol, purified $\mathrm{HC}$ interacted in vitro with an aphid-transmissible TuMV isolate, but not with a non-aphid-transmissible isolate.
Aphid transmission of potyviruses is dependent upon the presence of a virus-encoded nonstructural protein termed helper component (HC). So far, biologically active HCs have been purified from several potyviruses $(1,4,13)$, but a procedure that is effective for purification of a specific HC is very often not effective with another, even if the viruses are closely related and the HCs are produced in the same host plant. Only in the case of potato virus Y (PVY) and tobacco vein mottling virus (TVMV) has the molecular mass of the biologically active form of the $\mathrm{HC}$ been determined $(7,13)$.

Our recent research on the role of $\mathrm{HC}$ in determining vector specificity has shown that the HC of turnip mosaic virus (TuMV) can assist transmission of potyviruses by the turnip aphid (Lipaphis erysimi), whereas the HCs of tobacco etch virus (TEV) and PVY (which are fully functional in another aphid, Myzus persicae (Sulzer)) cannot (14; R. Y. Wang and T. P. Pirone, unpublished data). The studies reported here were done to obtain purified TuMV $\mathrm{HC}$ and compare its properties with those of PVY HC as a basis for further studies to determine why they function differently in these aphids.

\section{MATERIALS AND METHODS}

Extraction of TuMV HC. The aphid-transmissible isolate of TuMV used was that reported by Sako (11). The virus was propagated in a greenhouse either in mustard (Brassica perviridis) or in turnip (B. rapa) for 4 weeks prior to purification attempts. The initial steps and partial purification generally followed the procedures of Sako (11) and Sako and Ogata (12). Infected leaves were homogenized in 2 volumes (wt/vol) of $0.5 \mathrm{M}$ potassium phosphate buffer $(\mathrm{KPB}), \mathrm{pH} 8.5$, and centrifuged at 8,000 $\times \mathrm{g}$ for $15 \mathrm{~min}$. This and subsequent steps were carried out on ice or at $4^{\circ} \mathrm{C}$. The supernatant was centrifuged at $120,000 \times g$ for $1 \mathrm{~h}$ to pellet the virus particles. Powdered ammonium sulfate was added to the su-

Corresponding author: T. P. Pirone; E-mail address: tpirone@pop.uky.edu

Publication no. P-1999-0427-01R

(C) 1999 The American Phytopathological Society pernatant with stirring for $10 \mathrm{~min}$. The solution was incubated for another $20 \mathrm{~min}$ without stirring and then centrifuged at 8,000 $\times g$ for $15 \mathrm{~min}$. The precipitate was resuspended $(1 / 5$ of the supernatant volume) in $0.02 \mathrm{M} \mathrm{KPB}, \mathrm{pH} 7.5$, and centrifuged at 5,000 $\times g$ for 10 min. Details of further steps in TuMV HC purification are given below.

Aphid rearing and handling. $M$. persicae were reared on mustard under previously described conditions (10). Apterous aphids were collected and kept in glass vials for 2 to $3 \mathrm{~h}$ of preacquisition fasting. General procedures for membrane acquisition have been described elsewhere (6).

Testing HC activity. The activity of TuMV HC preparations was determined by transmission tests using $M$. persicae fed on a mixture of the $\mathrm{HC}$ and $100 \mu \mathrm{g}$ of purified virions per ml. Two sources of virions were used. TEV rapidly produces easily recognizable symptoms on tobacco, and TuMV HC supports the transmission of TEV by $M$. persicae (14). Thus, virions of a highly aphid-transmissible strain of TEV (6), purified by the method of Murphy et al. (5), were used in most tests. TuMV virions, propagated in mustard and purified by a combination of the methods of Murphy et al. (5) and Sako (11), were also used in some tests. PVY HC, which readily assists TEV transmission (8), was used as a positive control. Sucrose gradient-purified PVY HC was prepared as described previously (13).

Aphids were placed in a feeding chamber for a 10-min acquisition access period. Those aphids that were still on the membrane at the end of the acquisition access period were transferred onto seedlings of either tobacco (Nicotiana tabacum L. cv. Kentucky 14), when TEV was used, or mustard, when TuMV was used. Ten aphids per test plant were used in all cases. Aphids were allowed to remain on the test plants overnight (14 to $18 \mathrm{~h}$ ), after which plants were sprayed with an insecticide and placed in a growth room for symptom development.

Sodium dodecyl sulfate-polyacrylamide gel electrophoresis (SDS-PAGE) analysis. HC preparations were mixed with an equal volume of protein dissociation buffer $(0.5 \mathrm{M}$ Tris- $\mathrm{HCl}, \mathrm{pH} 6.8$; $4 \%$ SDS; $10 \%$ 2-mercaptoethanol; and $10 \%$ glycerol), boiled for $10 \mathrm{~min}$, and electrophoresed on 12\% SDS-PAGE. Separated proteins were detected by staining with Coomassie brilliant blue or were transferred to nitrocellulose for western blot analysis. Either 
polyclonal or monoclonal antibodies to TVMV HC, both of which react with TuMV HC (R. Y. Wang and T. P. Pirone, unpublished data), were used at optimal concentrations in the western blot analyses.

Molecular mass estimation. The molecular mass of TuMV HC in its dissociated state was determined by SDS-PAGE and that of nondissociated TuMV HC was determined by membrane ultrafiltration and gel filtration. Further details of these procedures are given below.

Interaction between the $\mathrm{HC}$ and different TuMV isolates. A protein blotting-overlay protocol (2) was used to assess the interaction between viral coat proteins and the HC. The aphid-transmissible TuMV (isolate 1) that was used in our HC purification and a non-aphid-transmissible TuMV (isolate 31) reported by Sako (11) were purified in the same way. Viral coat protein was denatured by boiling purified virions for $10 \mathrm{~min}$ in protein dissociation

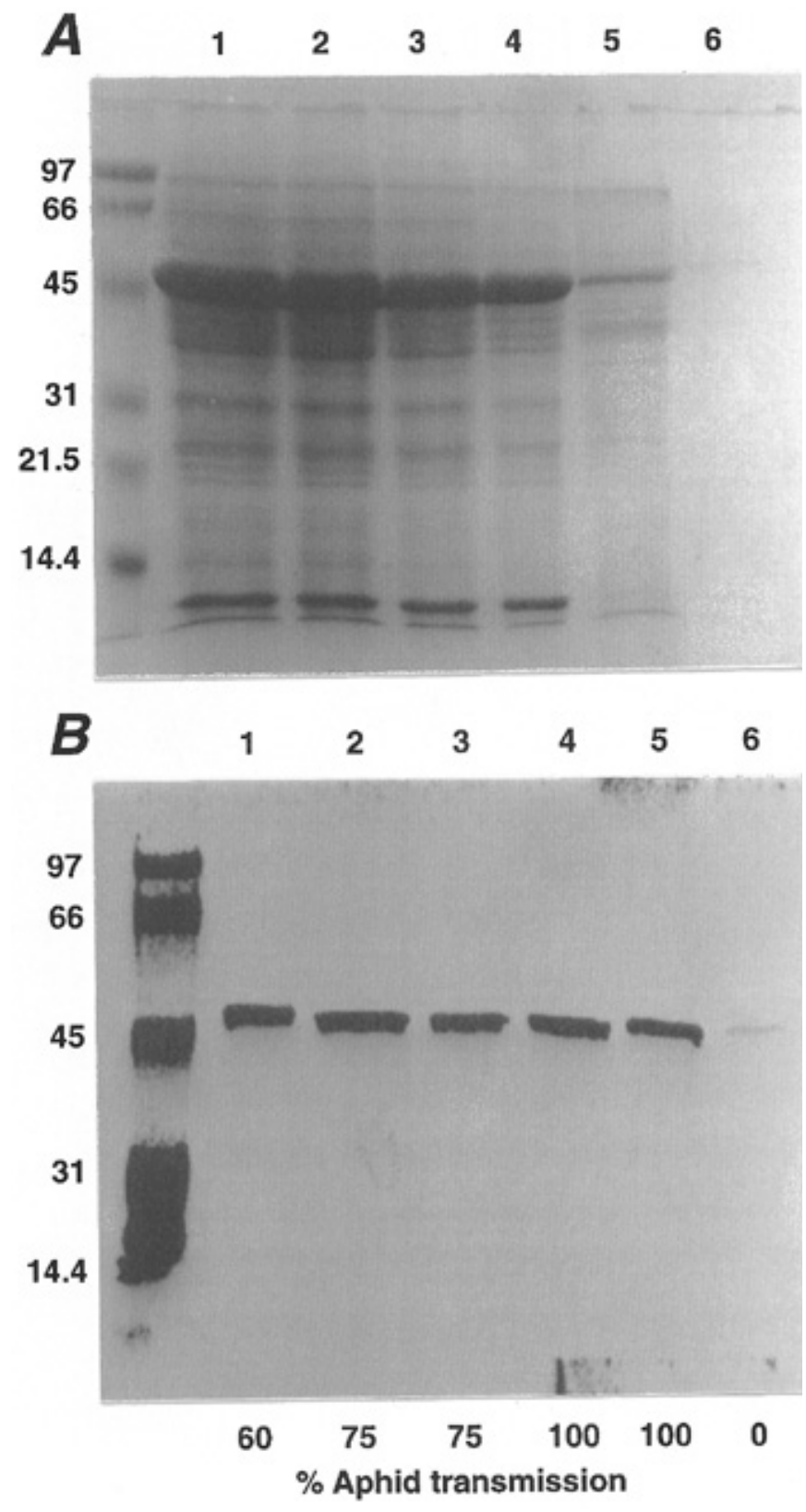

Fig. 1. Precipitation of turnip mosaic virus helper component (HC) protein by different concentrations of ammonium sulfate: lane 1, 60\%; lane 2, 50\%; lane 3,40\%; lane 4, 30\%; lane 5,20\%; and lane 6, 10\%. A, Coomassie blue staining; and $\mathbf{B}$, western blot analysis using a monoclonal antibody to the HC. The results of aphid-transmission tests are shown at the bottom of the figure. The percentage of infected plants was the average of two separate tests (10 assay plants per treatment, 10 aphids per plant). buffer, electrophoresed on $12 \%$ SDS-PAGE, and transferred onto a nitrocellulose membrane. The membrane was incubated for $24 \mathrm{~h}$ at $4{ }^{\circ} \mathrm{C}$ in $0.02 \mathrm{M} \mathrm{KPB}, \mathrm{pH} 7.5$, containing $5 \%$ dry skim milk powder to allow both a partial renaturation of the proteins and blockage of nonspecific reaction sites. The membrane was then incubated overnight at $4^{\circ} \mathrm{C}$ with purified $\mathrm{HC}$ in $0.02 \mathrm{M} \mathrm{KPB}$, followed by three 10-min washes in 0.02 M KPB and one wash in $0.1 \mathrm{M}$ Tris$\mathrm{HCl}, 0.5 \mathrm{M} \mathrm{NaCl}$, and $0.02 \%$ Tween-20, pH 7.5. The membrane was probed with a monoclonal antibody to TVMV HC for a minimum of $4 \mathrm{~h}$ at $4^{\circ} \mathrm{C}$, and specific reactions were detected as for western blot analysis. Purified HC was electrophoresed and transferred onto the membrane as an internal positive control. Aphidtransmission tests were conducted to confirm the aphid transmissibility of the TuMV isolates.

\section{RESULTS AND DISCUSSION}

Purification of TuMV HC. The addition of ammonium sulfate to $60 \%$ saturation to concentrate $\mathrm{HC}$ as described by Sako and Ogata (12) resulted in the precipitation of many extraneous proteins. Thus, it was necessary to determine an optimum concentration of ammonium sulfate for precipitation of the HC from the high-speed supernatant. A series of amounts of powdered ammonium sulfate was added to the supernatant with stirring for $10 \mathrm{~min}$. The solution was incubated for another $20 \mathrm{~min}$ without stirring and then centrifuged at 8,000 $\times \mathrm{g}$ for $15 \mathrm{~min}$. The precipitate was dissolved in $0.02 \mathrm{M} \mathrm{KPB}(1 / 5$ of supernatant volume), $\mathrm{pH} 7.5$, and centrifuged at 5,000 $\times g$ for $10 \mathrm{~min}$. After resuspension of the pellet, samples were prepared for SDSPAGE followed by Coomassie staining or western blot analysis and for aphid-transmission tests. As expected, more proteins, particularly Rubisco, were precipitated at the higher ammonium sulfate concentrations (Fig. 1A). Increasing the ammonium sulfate concentration above $20 \%$ also resulted in decreased efficiency of aphid transmission (Fig. 1B), presumably because the extraneous proteins interfered with the interaction of the $\mathrm{HC}$ with virions or the aphid food canal. However, the amount of HC precipitated was relatively constant at ammonium sulfate concentrations of $20 \%$ or higher (Fig. 1B). Further refinement determined that the optimal concentration was $18 \%$ (data not shown).

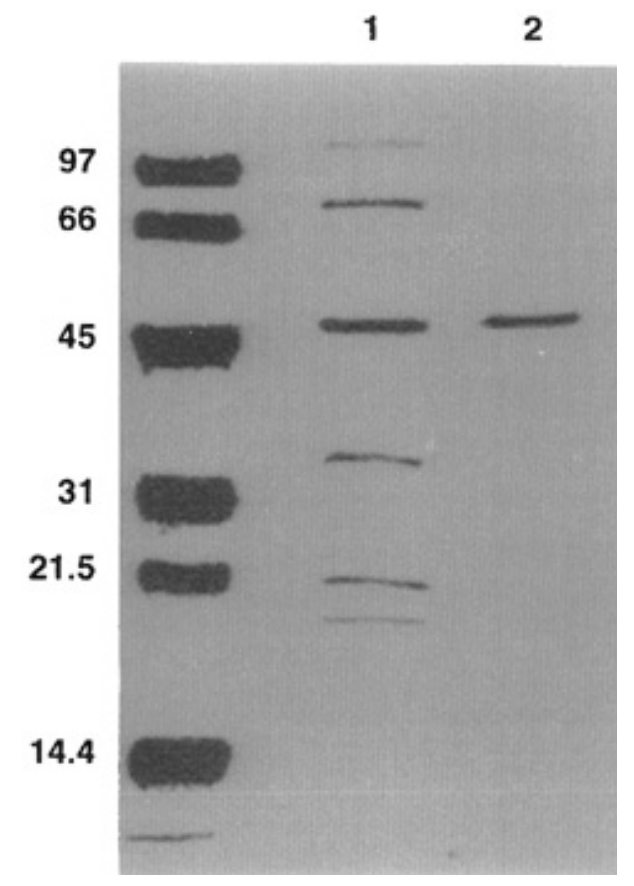

Fig. 2. Western blot analysis, using a polyclonal antibody to the helper component $(\mathrm{HC})$ protein, for the molecular mass estimation of denatured turnip mosaic virus HC. Lane 1, After resuspension of the ammonium sulfate pellet; and lane 2, after final purification. 
TABLE 1. Results of tests of turnip mosaic virus helper component stability at different stages of purification

\begin{tabular}{|c|c|c|c|c|c|c|c|c|c|c|}
\hline \multirow[b]{2}{*}{ Stage of purification } & \multirow{2}{*}{$\begin{array}{c}\text { Storage } \\
\text { temperature }\left({ }^{\circ} \mathrm{C}\right)\end{array}$} & \multicolumn{9}{|c|}{$\%$ Aphid transmission after } \\
\hline & & $3 \mathrm{~h}$ & $8 \mathrm{~h}$ & 1 day & 2 days & 1 week & 2 weeks & 1 month & 2 months & 4 months \\
\hline \multirow[t]{2}{*}{ Low-speed supernatant } & 4 & $65^{\mathrm{a}}$ & 15 & 0 & $\ldots^{\mathrm{b}}$ & $\ldots$ & $\ldots$ & $\ldots$ & $\ldots$ & $\ldots$ \\
\hline & -20 & $\ldots$ & $\ldots$ & 70 & 40 & 0 & 0 & $\ldots$ & $\ldots$ & $\ldots$ \\
\hline \multirow[t]{2}{*}{ High-speed supernatant } & 4 & 80 & 35 & 0 & $\ldots$ & $\ldots$ & $\ldots$ & $\ldots$ & $\ldots$ & $\ldots$ \\
\hline & -20 & $\ldots$ & $\ldots$ & 90 & 40 & 15 & 0 & $\ldots$ & $\ldots$ & $\ldots$ \\
\hline \multirow[t]{2}{*}{ Resuspended precipitate $^{\mathrm{c}}$} & 4 & 100 & 80 & 30 & 0 & $\ldots$ & $\ldots$ & $\ldots$ & $\ldots$ & $\ldots$ \\
\hline & -20 & $\ldots$ & $\ldots$ & 100 & 100 & 100 & 100 & 90 & 90 & 75 \\
\hline \multirow[t]{2}{*}{ Column eluate $^{\mathrm{c}}$} & 4 & 100 & 100 & 30 & 0 & $\ldots$ & $\ldots$ & $\ldots$ & $\ldots$ & $\ldots$ \\
\hline & -20 & $\ldots$ & $\ldots$ & 100 & 100 & 100 & 100 & 95 & 100 & 100 \\
\hline
\end{tabular}

a Average of two separate aphid-transmission tests. Ten aphids were placed on each of 10 test plants for each treatment.

b Not tested.

c Tested at 1:4 dilution.

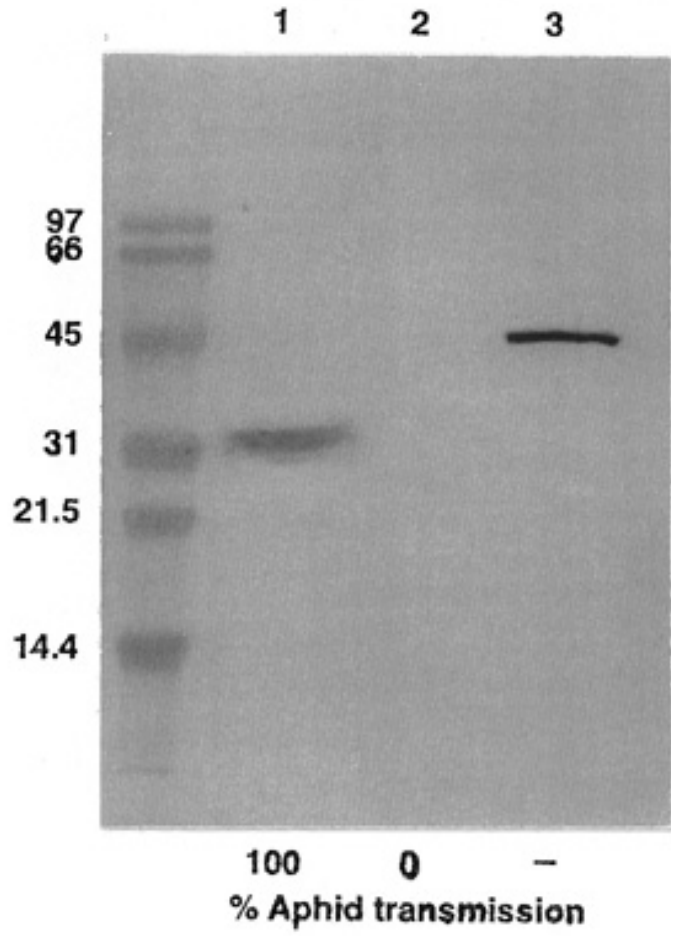

Fig. 3. Results of protein blotting-overlay tests showing the correlation between aphid transmission and binding between the helper component (HC) protein and viral coat protein. Viral coat protein was denatured, electrophoresed on sodium dodecyl sulfate-polyacrylamide gel electrophoresis, and transferred onto a nitrocellulose membrane. The membrane was then incubated with purified $\mathrm{HC}$ followed by probing with a monoclonal $\mathrm{HC}$ antibody. Lane 1, An aphid-transmissible turnip mosaic virus (TuMV) isolate (isolate 1). Lane 2, A non-aphid-transmissible isolate (isolate 31). Lane 3, Purified TuMV HC as an internal positive control. The results of aphid-transmission tests (10 assay plants per treatment, 10 aphids per plant) are shown at the bottom of the figure.

For further purification, $1 \mathrm{ml}$ of Ni-NTA Agarose (Qiagen, Santa Clarita, CA) preequilibrated with $0.02 \mathrm{M} \mathrm{KPB}, \mathrm{pH} 7.5$, was added to $10 \mathrm{ml}$ of the supernatant and shaken vigorously on ice for $30 \mathrm{~min}$. The solution was loaded into a polypropylene column $(9 \mathrm{~mm}$ in diameter) (Qiagen), and the liquid was allowed to flow through by gravity. The column was rinsed with $10 \mathrm{ml}(5 \mathrm{ml}+3 \mathrm{ml}+2 \mathrm{ml})$ of $0.02 \mathrm{M} \mathrm{KPB}$. The column outlet was then plugged and $3 \mathrm{ml}$ of $0.4 \mathrm{M}$ EGTA (ethylene glycol-bis( $\beta$-aminoethyl ether)- $N, N, N^{\prime}, N^{\prime}$ tetraacetic acid) adjusted to $\mathrm{pH} 7.3$ with $\mathrm{NaOH}$ was added, mixed well with the Ni-NTA Agarose in the column, and allowed to incubate for $5 \mathrm{~min}$. The column was unplugged and the flow-through solution was collected and dialyzed against two changes of $0.02 \mathrm{M}$ KPB overnight to remove the EGTA. A comparison of the amount of the HC present before and after adsorption to and elution from the column is presented in Figure 2. For use in aphid-transmission tests, powdered sucrose was added to a final concentration of $10 \%$ (wt/vol). The final solution was aliquoted into small volumes, flash frozen with liquid nitrogen, and stored at $-20^{\circ} \mathrm{C}$.

To test stability, HC preparations at different stages of purification were stored at 4 or $-20^{\circ} \mathrm{C}$. Aphid-transmission tests were conducted using these preparations after different periods of time in storage (Table 1). Purified virions were added to the $\mathrm{HC}$ and acquired by aphids through membranes. TuMV HC was very unstable at the early stages of the purification process; even when stored at $-20^{\circ} \mathrm{C}$, activity was lost after 1 to 2 weeks. As purification progressed, the HC became more stable. The final product was tested after storage for 4 months at $-20^{\circ} \mathrm{C}$ and had not lost activity (Table 1).

Sako (11) first reported that active TuMV HC could be obtained when TuMV-infected plants were homogenized in $0.5 \mathrm{M} \mathrm{KPB}, \mathrm{pH}$ 8.5 , followed by low-speed centrifugation. Later, Sako and Ogata (12) were able to concentrate the HC from a high-speed supernatant by adding ammonium sulfate to $60 \%$ saturation. However, the instability of their HC precluded dialysis and further purification. Compared with PVY HC or TVMV HC, TuMV HC is very unstable during the purification process; at the early stages of purification in our experiments, TuMV HC lost activity quickly even at $-20^{\circ} \mathrm{C}$. This indicated that $\mathrm{HC}$ inactivation was due to chemical rather than enzymatic reactions. Attempts to incorporate additives (Na-DIECA [diethyldithiocarbamic acid], Na-EDTA, Triton X-100, $\mathrm{Na}_{2} \mathrm{SO}_{4}$, and 2-mercaptoethanol) into the extraction buffer or use different buffers to stabilize the HC were unsuccessful.

Immobilized-metal affinity chromatography was first used to purify proteins in 1975 (9). Later, Hochuli et al. (3) found that nitrilotriacetic acid binds metal ions far more stably than other chelating resins, and it has selective affinity for proteins and peptides containing neighboring histidine residues. $\mathrm{Ni}^{2+}$ columns are now used extensively to purify $6 \times$ histidine-tagged proteins. Use of a $\mathrm{Ni}^{2+}$ column without a histidine tag was shown to be useful in purification of zucchini yellow mosaic virus HC (4), and our success with TuMV HC initially suggested that it might be generally useful for HC purification. However, our attempts to use this method for purification of PVY, TVMV, and TEV HCs have been unsuccessful, again pointing out that no one method is likely to be generally applicable for HC purification.

Interaction between the $\mathrm{HC}$ and different TuMV isolates. The specificity of binding of purified TuMV HC was tested in protein blotting-overlay tests. Purified HC bound to the viral coat protein of an aphid-transmissible TuMV (isolate 1), but not to the nonaphid-transmissible TuMV (isolate 31) (Fig. 3).

Molecular mass estimation of the HC. In western blot analyses using polyclonal antibodies, a major band of approximately $50 \mathrm{kDa}$, along with five other bands (presumably $\mathrm{HC}$ aggregation or breakdown products), was produced by the resuspended $20 \%$ ammonium sulfate precipitate. After affinity purification on the $\mathrm{Ni}^{2+}$ column, only the $50-\mathrm{kDa}$ band was present (Fig. 2).

The molecular mass of undissociated TuMV HC was estimated by membrane ultrafiltration and by gel filtration. In both cases, $1 \mathrm{ml}$ of purified $\mathrm{HC}$ was mixed with $1 \mathrm{ml}$ of $0.02 \mathrm{M} \mathrm{KPB}$. For ultrafiltration, the solution was loaded onto Centricon-30 membrane filters 


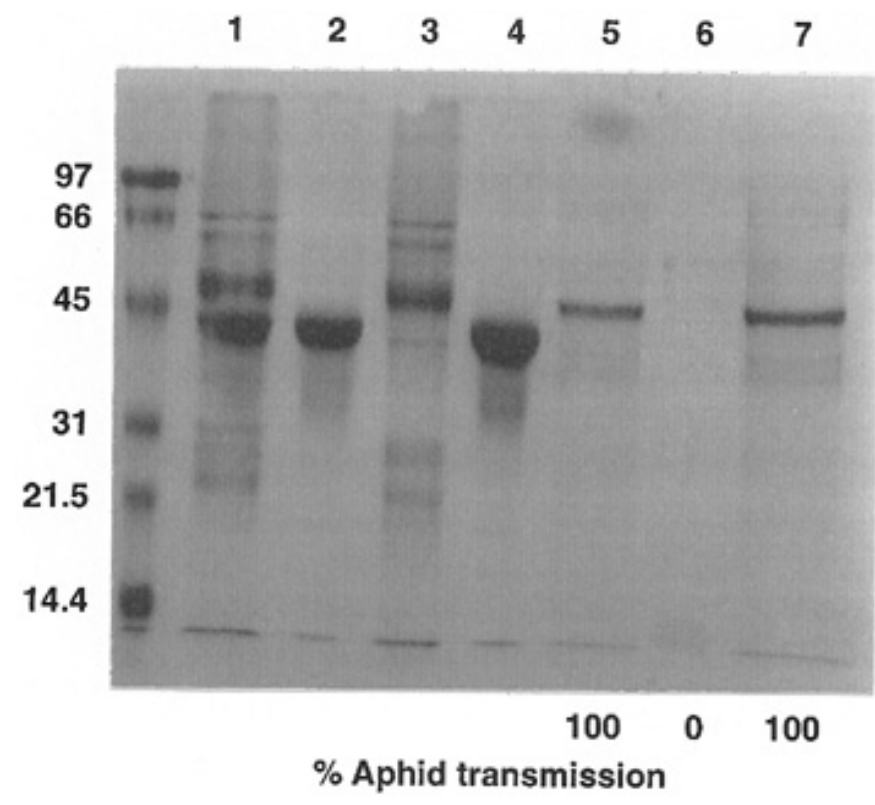

Fig. 4. Sodium dodecyl sulfate-polyacrylamide gel electrophoresis results for Centricon-100 ultrafiltration of nondissociated turnip mosaic virus (TuMV) helper component (HC) protein. Lane 1, Solution retained above the membrane from a mixture of two proteins, immunoglobulin $\mathrm{G}(\mathrm{IgG})(170 \mathrm{kDa})$ and ovalbumin $(67 \mathrm{kDa})$. Lane 2 , Solution filtered through the membrane from a mixture of $\operatorname{IgG}$ and ovalbumin. Lane 3, IgG only. Lane 4, Ovalbumin only. Lane 5, Purified TuMV HC. Lane 6, TuMV HC solution that passed through the membrane. Lane 7, TuMV HC solution retained by the membrane. The results of aphid-transmission tests (10 assay plants per treatment, 10 aphids per plant) are shown at the bottom of the figure.

(Amicon, Inc., Beverly, MA), with a cutoff of $30 \mathrm{kDa}$, and Centricon100 filters, with a cutoff of $100 \mathrm{kDa}$. The samples were centrifuged at $5,000 \times g$ until about $0.5 \mathrm{ml}$ remained above the membrane. After centrifugation, the solution retained above the membrane and the membrane filtrate were collected. Sucrose (10\% final concentration) and purified virions were added, and aphid-transmission tests were conducted to check the biological activity of the two HC solutions. Samples were also prepared for SDS-PAGE analysis. Two proteins of known molecular mass were loaded onto the membranes as internal controls. As expected, purified $\mathrm{HC}$ could not pass through the 30-kDa cutoff, as evidenced both by aphid-transmission tests and SDS-PAGE analysis (data not shown); nor did the HC pass through the 100-kDa-cutoff filter (Fig. 4). These results indicated that biologically active $\mathrm{HC}$ is not in the monomer form.

For gel filtration, a $15 \times 500-\mathrm{mm}$ column of Sephacryl S-200 HR (Pharmacia Biotech, Uppsala, Sweden), having a fractionation range of 5 to $250 \mathrm{kDa}$, was equilibrated with $0.02 \mathrm{M} \mathrm{KPB}$. One milliliter of purified $\mathrm{HC}$ was loaded on the column and then eluted with the same buffer at a flow rate of $6 \mathrm{ml} / \mathrm{h}$. The absorbance of the eluate was continuously monitored at $280 \mathrm{~nm}$ while $3-\mathrm{ml}$ fractions were collected. Purified virions were added to the fractions within the absorbance peak and assayed by aphid transmission. Samples from the same fractions were also prepared for western blot analysis. Marker proteins $(5 \mathrm{mg} / \mathrm{ml})$ were applied and eluted in the same manner in separate experiments. The $\mathrm{HC}$ was eluted from the column as a single peak corresponding to a molecular mass of approximately $145 \mathrm{kDa}$, based on its position relative to the protein markers (Fig. 5). The results of the aphid-transmission tests matched the profile of the elution peak (Fig. 5). The presence of the $\mathrm{HC}$ in these fractions was confirmed by the western blot analysis (data not shown). These results indicate that biologically active TuMV HC is in a multimeric form.

This is the third HC for which the molecular mass of the undissociated protein has been determined. The subunit molecular mass and that of the biologically active TuMV HC multimer are similar to those of the PVY and TVMV HCs (13). The question arises as

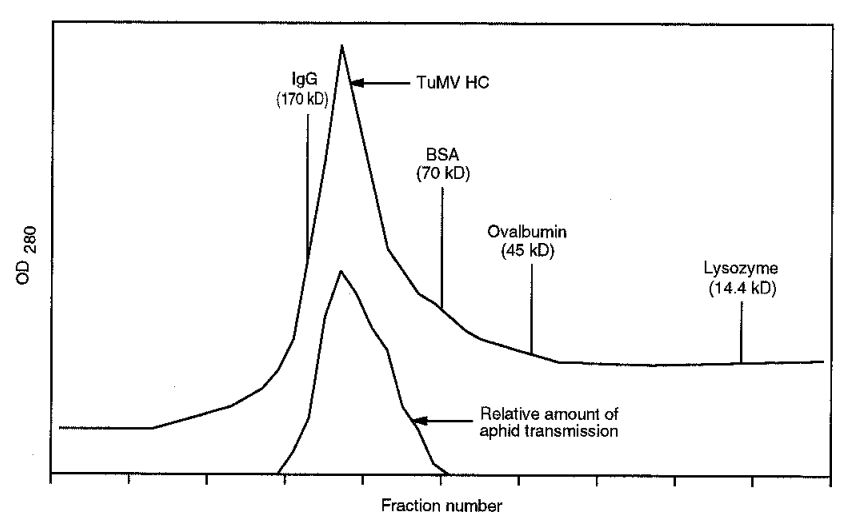

Fig. 5. Elution of purified turnip mosaic virus helper component $(\mathrm{HC})$ protein from a $15 \times 500$-mm Sephacryl S-200 HR column. The UV absorption profile and the profile of the relative ability of the eluate to affect aphid transmission of purified virions and the position of protein standards are marked.

to whether there is a relationship between the ability of HCs to be purified by different procedures or to be stabilized by different media and their ability to function in different aphid species. The availability of purified TuMV HC will make possible comparative studies of the chemical/physical properties of these HCs and their ability to function in different aphid species.

\section{ACKNOWLEDGMENTS}

This research was supported, in part, by a grant from R. J. Reynolds Corporation. We thank R. Jordan (USDA, Beltsville, MD) for providing the monoclonal antibodies.

\section{LITERATURE CITED}

1. Blanc, S., Dolja, V. V., Llave, C., and Pirone, T. P. 1999. Histidine-tagging and purification of tobacco etch potyvirus helper component protein. J. Virol. Methods 77:11-15.

2. Blanc, S., Lopez-Moya, J. J., Wang, R. Y., Garcia-Lampasona, S., Thornbury, D. W., and Pirone, T. P. 1997. A specific interaction between coat protein and helper component correlates with aphid transmission of a potyvirus. Virology 231:141-147.

3. Hochuli, E., Dobeli, H., and Schacher, A. 1987. New metal chelate adsorbent selective for proteins and peptides containing neighboring histidine residues. J. Chromatogr. 411:177-184.

4. Kadoury, D., Peng, Y.-H., Wang, Y., Singer, S., Huet, H., Raccah, B., and Gal-On, A. 1998. Affinity purification of HC-Pro of potyviruses with Ni2+-NTA resin. J. Virol. Methods 76:19-29.

5. Murphy, J. F., Rhoads, R. E., Hunt, A. G., and Shaw, J. G. 1990. The VPg of tobacco etch virus RNA is the 49-KDa proteinase or the N-terminal 24-KDa part of the proteinase. Virology 178:285-288.

6. Pirone, T. P. 1981. Efficiency and selectivity of the helper-componentmediated aphid transmission of purified potyviruses. Phytopathology 71: 922-924.

7. Pirone, T. P., and Blanc, S. 1996. Helper-dependent vector transmission of plant viruses. Annu. Rev. Phytopathol. 34:227-247.

8. Pirone, T. P., and Thornbury, D. W. 1983. Role of virion and helper component in regulating aphid transmission of tobacco etch virus. Phytopathology 73:872-875.

9. Porath, J., Carlsson, J., Olsson, I., and Belfrage, G. 1975. Metal chelate affinity chromatography, a new approach to protein fractionation. Nature 258:598-599.

10. Raccah, B., and Pirone, T. P. 1984. Characteristics of and factors affecting helper-component-mediated aphid transmission of a potyvirus. Phytopathology 74:305-308.

11. Sako, N. 1980. Loss of aphid transmissibility of turnip mosaic virus. Phytopathology 70:647-649.

12. Sako, N., and Ogata, K. 1981. A helper factor essential for aphid transmissibility of turnip mosaic virus. Ann. Phytopathol. Soc. Jpn. 47:68-70.

13. Thornbury, D. W., Hellmann, G. M., Rhoads, R. E., and Pirone, T. P. 1985. Purification and characterization of potyvirus helper component. Virology 144:260-267.

14. Wang, R. Y., Powell, G., Hardie, J., and Pirone, T. P. 1998. Role of the helper component in vector-specific transmission of potyviruses. J. Gen. Virol. 79:1519-1524. 